\title{
Front Matter: Volume 9431
}

, "Front Matter: Volume 9431," Proc. SPIE 9431, Active and Passive Smart Structures and Integrated Systems 2015, 943101 (11 May 2015); doi: $10.1117 / 12.2196353$

SPIE Event: SPIE Smart Structures and Materials + Nondestructive Evaluation and SPIE. Health Monitoring, 2015, San Diego, California, United States 


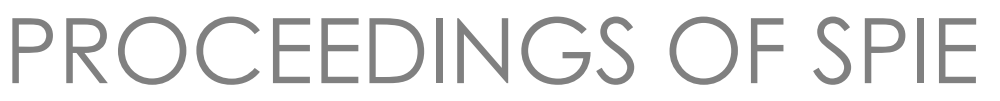

\title{
Active and Passive Smart Structures and Integrated Systems 2015
}

\author{
Wei-Hsin Liao \\ Gyuhae Park \\ Alper Erturk \\ Editors
}

9-12 March 2015

San Diego, California, United States

Sponsored by

SPIE

Cosponsored by

American Society of Mechanical Engineers (United States)

Cooperating Organizations

Intelligent Materials Forum (Japan)

Jet Propulsion Laboratory (United States)

National Science Foundation (United States)

Published by

SPIE 
The papers included in this volume were part of the technical conference cited on the cover and title page. Papers were selected and subject to review by the editors and conference program committee. Some conference presentations may not be available for publication. The papers published in these proceedings reflect the work and thoughts of the authors and are published herein as submitted. The publisher is not responsible for the validity of the information or for any outcomes resulting from reliance thereon.

Please use the following format to cite material from this book:

Author(s), "Title of Paper," in Active and Passive Smart Structures and Integrated Systems 2015, edited by Wei-Hsin Liao, Gyuhae Park, Alper Erturk, Proceedings of SPIE Vol. 9431 (SPIE, Bellingham, WA, 2015) Article CID Number.

ISSN: 0277-786X

ISBN: 9781628415346

Published by

SPIE

P.O. Box 10, Bellingham, Washington 98227-0010 USA

Telephone +1 3606763290 (Pacific Time) · Fax +1 3606471445

SPIE.org

Copyright (C) 2015, Society of Photo-Optical Instrumentation Engineers.

Copying of material in this book for internal or personal use, or for the internal or personal use of specific clients, beyond the fair use provisions granted by the U.S. Copyright Law is authorized by SPIE subject to payment of copying fees. The Transactional Reporting Service base fee for this volume is $\$ 18.00$ per article (or portion thereof), which should be paid directly to the Copyright Clearance Center (CCC), 222 Rosewood Drive, Danvers, MA 01923. Payment may also be made electronically through CCC Online at copyright.com. Other copying for republication, resale, advertising or promotion, or any form of systematic or multiple reproduction of any material in this book is prohibited except with permission in writing from the publisher. The CCC fee code is 0277-786X/15/\$18.00.

Printed in the United States of America.

Publication of record for individual papers is online in the SPIE Digital Library.

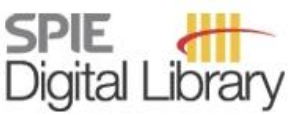

SPIEDigitalLibrary.org

Paper Numbering: Proceedings of SPIE follow an e-First publication model, with papers published first online and then in print. Papers are published as they are submitted and meet publication criteria. A unique citation identifier (CID) number is assigned to each article at the time of the first publication. Utilization of CIDs allows articles to be fully citable as soon as they are published online, and connects the same identifier to all online, print, and electronic versions of the publication. SPIE uses a six-digit CID article numbering system in which:

- The first four digits correspond to the SPIE volume number.

- The last two digits indicate publication order within the volume using a Base 36 numbering

system employing both numerals and letters. These two-number sets start with 00, 01, 02, 03, 04, $05,06,07,08,09,0 A, 0 B \ldots$. OZ, followed by 10-1Z, 20-2Z, etc.

The CID Number appears on each page of the manuscript. The complete citation is used on the first page, and an abbreviated version on subsequent pages. 


\title{
Contents
}

\author{
xi Authors \\ xv Conference Committee
}

\section{Part One}

\section{SESSION 1 ENERGY HARVESTING AND SCAVENGING: WAVES/ACOUSTICS}

943102 Broadband performance of a patterned piezoelectric energy harvester integrated with a continuous elastoacoustic mirror [9431-1]

943103 On the use of nonlinear solitary waves for energy harvesting [9431-2]

943104 Hydraulic pressure energy harvester enhanced by Helmholtz resonator [9431-3]

943105 An experimentally validated contactless acoustic energy transfer model with resistivereactive electrical loading [9431-4]

943106 Energy scavenging from acousto-elastic metamaterial using local resonance phenomenon [9431-5]

\section{SESSION 2 MAGNETO RHEOLOGICAL SYSTEMS I}

943108 A prosthetic knee using magnetorhelogical fluid damper for above-knee amputees [9431-7]

943109 Behavior of a flexible controllable micropump [9431-8]

9431 OA Design of energy-efficient MRF-based clutches with defined fail-safe behavior for integration in hybrid powertrains [9431-9]

\section{SESSION 3 ENERGY HARVESTING AND SCAVENGING: FLUID-STRUCTURE INTERACTION}

$9431 \mathrm{OB}$ Underwater energy harvesting from vibrations of annular ionic polymer metal composites [9431-10]

9431 OC Unified electrohydroelastic investigation of underwater energy harvesting and dynamic actuation by incorporating Morison's equation [9431-11]

9431 OD Transfer matrix modeling of a tensioned piezo-solar hybrid energy harvesting ribbon [9431-12] 
9431 OE Enhancement of galloping-based wind energy harvesting by synchronized switching interface circuits [9431-13]

9431 OF A hydrostatic pressure-cycle energy harvester [9431-14]

9431 OG A new energy harvester for fluids in motion [9431-15]

SESSION 4 BIOLOGICAL-INSPIRED SYSTEMS AND BIO-MEMS

$9431 \mathrm{OH} \quad$ Fluidic origami cellular structure: combining the plant nastic movements with paper folding art [9431-16]

9431 ol Nylon-muscle-actuated robotic finger [9431-18]

SESSION 5 ENERGY HARVESTING AND SCAVENGING: BROADBAND/NONLINEAR I

$9431 \mathrm{OL} \quad$ An investigation on vibration energy harvesting using nonlinear dynamic principles inspired by trees [9431-19]

$94310 \mathrm{M}$ Piezoelectric cantilever-pendulum for multi-directional energy harvesting with internal resonance [9431-20]

943100 Chaotic control of a piezomagnetoelastic beam for improved energy harvesting [9431-22]

SESSION 6 ENERGY HARVESTING AND SCAVENGING: BROADBAND/NONLINEAR II

9431 OP Vibration energy harvesting from a nonlinear standing beam-mass system using a two-mode approximation [9431-23]

$94310 Q \quad$ A diamagnetically stabilized horizontally levitated electromagnetic vibration energy harvester [9431-24]

9431 OR Piezoelectric energy harvesting with a nonlinear energy sink [9431-25]

9431 OS Tunable bistable devices for harvesting energy from spinning wheels [9431-26]

SESSION 7 AIRCRAFT, MAV/UAV, AND MORPHING SYSTEMS

9431 OT Spanwise morphing trailing edge on a finite wing [9431-27]

9431 OU Modeling and development of a twisting wing using inductively heated shape memory alloy actuators [9431-28]

9431 OV Multimodal sensing strategies for detecting transparent barriers indoors from a mobile plafform [9431-29] 
9431 OX A robust two-way switching control system for remote piloting and stabilization of low-cost quadrotor UAVs [9431-31]

9431 OY Planform, aero-structural, and flight control optimization for tailless morphing aircraft [9431-32]

SESSION 8A ENERGY HARVESTING AND SCAVENGING: PIEZOELECTRICS/ELECTRECTS

943110 Bimorph disk piezoelectric energy harvester under base excitation: electroelastic modeling and experimental validation [9431-34]

943111 Evaluation of piezoelectret foam in a multilayer stack configuration for low-level vibration energy harvesting applications [9431-35]

SESSION 8B MICRO- AND NANO-INTEGRATED SYSTEMS

943112 Force-compensated hydrogel-based pH sensor [9431-36]

943113 Integration of fluidic jet actuators in composite structures [9431-37]

SESSION 9A SMA-BASED MATERIALS AND SYSTEMS I

943115 Experimental investigation of bond in concrete members reinforced with shape memory alloy bars [9431-39]

943116 Adaptive and energy efficient SMA-based handling systems [9431-40]

943117 Shape-retainment control using an antagonistic shape memory alloy system [9431-41]

SESSION 9B PASSIVE AND ACTIVE VIBRATION ISOLATION SYSTEMS I

943119 Magnetoelastic metastructures for passive broadband vibration suppression [9431-43]

9431 1A Multimodal vibration damping through a periodic array of piezoelectric patches connected to a passive network [9431-44]

9431 1B Static and quasi-static behavior of an adaptive system to compensate path errors for smart fiber placement [9431-45]

9431 IC Adaptive-passive control of noise radiation of gear-box systems using a pair of shunted piezo-based rotating inertial actuators [9431-46]

SESSION 10A ENERGY HARVESTING AND SCAVENGING: GENERAL PIEZOELECTRICS

$9431 \mathrm{IE} \quad$ Embedded piezoelectrics for sensing and energy harvesting in total knee replacement units [9431-48] 
9431 1G A mechanical solution of self-powered SSHI interface for piezoelectric energy harvesting systems [9431-50]

SESSION 1OB MODELING, OPTIMIZATION, SIGNAL PROCESSING, SENSING, CONTROL, AND DESIGN OF INTEGRATED SYSTEMS I

9431 1H Damage identification in nonlinear periodic structures utilizing the dynamics of intrinsic localized modes [9431-51]

$943111 \quad$ Modeling and identification of nonlinear electroelastic and dissipative parameters for PZT-5A and PZT-5H bimorphs: a dynamical systems approach [9431-52]

$94311 \mathrm{~J}$ Design optimization of a magnetorheological brake in powered knee orthosis [9431-53]

\section{Part Two}

\section{SESSION 11A MAGNETO RHEOLOGICAL SYSTEMS II}

$9431 \mathrm{lL}$ Tactile device utilizing a single magnetorheological sponge: experimental investigation [9431-55]

9431 iN Force modeling for incision surgery into tissue with haptic application [9431-57]

943110 Optimization of new magnetorheological fluid mount for vibration control of start/stop engine mode [9431-58]

9431 iP Haptic cue control of an MR gear shifting assistance device via Preisach hysteresis linearization [9431-59]

\section{SESSION 11B PIEZO-BASED MATERIALS AND SYSTEMS}

9431 is Nonlinear vibration analysis of the high-efficiency compressive-mode piezoelectric energy harvester [9431-117]

9431 1T Removing surface accretions with piezo-excited high-frequency structural waves [9431-63]

9431 IV Multiobjective optimization of piezoelectric bimorph actuator with rigid extension [9431-65]

9431 IW Effect of material uncertainties on dynamic analysis of piezoelectric fans [9431-66] 
SESSION 12A MODELING, OPTIMIZATION, SIGNAL PROCESSING, SENSING, CONTROL, AND DESIGN OF INTEGRATED SYSTEMS II

9431 1X Multifunctional magneto-plasmonic nanotransducers for advanced theranostics: synthesis, modeling and experiment [9431-122]

9431 1Z A smart model of a long-span suspended bridge for wind tunnel tests [9431-69]

\section{SESSION 12B PASSIVE AND ACTIVE VIBRATION ISOLATION SYSTEMS II}

943120 Electromagnetic damper design using a multiphysics approach [9431-70]

943122 Vibration of cantilever piezolaminated beams with extension and shear mode piezo actuators [9431-72]

\section{SESSION 13A ENERGY HARVESTING AND SCAVENGING: APPLICATIONS}

943123 Magnetoelastic energy harvester for structural health monitoring applications [9431-73]

943126 Implementation of a robust hybrid rotary-translational vibration energy harvester for autonomous self-powered acceleration measurement [9431-76]

\section{SESSION 13B PASSIVE AND ACTIVE VIBRATION ISOLATION SYSTEMS III}

943127 Earthquake response reduction of mid-story isolated system due to semi-active control using magnetorheological rotary inertia mass damper [9431-77]

9431 2A Research on seismic performance of slotted RC walls with replaceable damper [9431-80]

SESSION 14A ENERGY HARVESTING AND SCAVENGING: GENERAL

$94312 \mathrm{~B} \quad$ Harvesting under transient conditions: harvested energy as a proxy for optimal resonance frequency detuning [9431-81]

9431 2C Electromagnetic energy harvester using coupled oscillating system with 2-degree of freedom [9431-82]

$94312 \mathrm{D}$ A single-DOF vibration energy harvester for integrating into the parallel mechanism [9431-83]

9431 2E A six-DOF vibration energy harvester based on the six-DOF parallel mechanism [9431-84] 
SESSION 14B MODELING, OPTIMIZATION, SIGNAL PROCESSING, SENSING, CONTROL, AND DESIGN OF INTEGRATED SYSTEMS III

$94312 \mathrm{~F}$ Simulating coupled thermal-mechanical interactions in morphing radiators (SPIE/ASME Best Student Paper Award) [9431-85]

$94312 \mathrm{G}$ A passive control methodology for seismic safety enhancement of monumental structures [9431-86]

$943121 \quad$ Investigation on seismic resistance of high-rising building installed with viscoelastic-wall dampers [9431-88]

\section{SESSION 15A SMA-BASED MATERIALS AND SYSTEMS II}

$94312 \mathrm{~J}$ Simulation and experimental studies of the SMA-activated needle behavior inside the tissue [9431-89]

$94312 \mathrm{~K}$ Optimization and testing of a continuous rotary motor based on shape memory wires and overrunning clutches [9431-90]

$94312 \mathrm{M}$ Modeling framework for materials capable of solid-solid phase transformation: application to the analytical solution of the semi-infinite mode III crack problem in an idealized shape memory alloy [9431-92]

$94312 \mathrm{~N}$ Experimental investigation on a novel 3D isolator made of shape memory alloy pseudo-rubber [9431-93]

943120 Improvement in performance of reinforced concrete structures using shape memory alloys [9431-94]

\section{SESSION 15B PASSIVE AND ACTIVE VIBRATION ISOLATION SYSTEMS IV}

$94312 \mathrm{P} \quad$ Adaptive active vibration control to improve the fatigue life of a carbon-epoxy smart structure [9431-95]

$94312 \mathrm{Q}$ Non-linear control logics for vibrations suppression: a comparison between model-based and non-model-based techniques [9431-96]

$943125 \quad$ Potential of viscous dampers for vibration mitigation of transmission overhead lines [9431-98]

$94312 T$ Design and investigation of a linear smart actuator [9431-99]

POSTER SESSION

$94312 \mathrm{~V}$ Use of spring-roll EAP actuator as end-effector of a hyper-redundant robot [9431-101] 
9431 2W Design of an innovative magnetostrictive patch actuator [9431-102]

$94312 \mathrm{X}$ Low frequency inertial control strategy for seismic attenuation with multi-stage mechanical suspensions [9431-103]

$94312 Z$ Passive vibration control in a building-like structure using a tuned-mass-damper and an autoparametric cantilever beam absorber [9431-105]

943130 Design and analysis of an innovative combined magneto-rheological damper-mount [9431-106]

943132 Hysteresis modeling and experimental validation of a magnetorheological damper [9431-108]

943133 Design of MR brake featuring tapered inner magnetic core [9431-109]

943136 Trajectory tracking and vibration control in a space frame flexible structure with a PZT stack actuator [9431-112]

943137 Wideband piezoelectric energy harvester for low-frequency application with plucking mechanism [9431-113]

943138 Sensor-less parameter estimation of electromagnetic transducer and experimental verification [9431-114]

943139 Enhanced piezoelectric energy harvesting of a bistable oscillator with an elastic magnifier [9431-115]

9431 3B Off-road motorbike performance analysis using a rear semi-active suspension [9431-119]

$94313 \mathrm{C}$ Comparisons of the dynamic characteristics of magnetorheological and hydraulic dampers [9431-120]

9431 3D Aerosol deposited PZT actuated 2D scanner system [9431-121] 
Proc. of SPIE Vol. $9431943101-10$

Downloaded From: https://www.spiedigitallibrary.org/conference-proceedings-of-spie on 26 Apr 2023 Terms of Use: https://www.spiedigitallibrary.org/terms-of-use 


\section{Authors}

Numbers in the index correspond to the last two digits of the six-digit citation identifier (CID) article numbering system used in Proceedings of SPIE. The first four digits reflect the volume number. Base 36 numbering is employed for the last two digits and indicates the order of articles within the volume. Numbers start with 00, 01, 02, 03, 04, 05, 06, 07, 08, 09, 0A, 0B...0Z, followed by 10-1Z, 20-2Z, etc.

Abdolhamidi, Shervin, OB

Abundis-Fong, H. F., $2 Z$

Acernese, F., $2 X$

Acevedo, Isaiah, OV

Adiba, Afifa, 06

Aglietti, Guglielmo S., 20

Ahmed, Riaz U., 06

Alujevic, N., 1C

Anton, Steven R., 11, 1E

Arafa, Mustafa, OS

Arrieta, Andres F., OY

Aucejo, Mathieu, IA

Bai, Xian-Xu, 32

Bajoria, Kamal M., 22, 20

Banerjee, Sourav, 06

Barone, F., $2 X$

Bassam, A., $2 S$

Baughman, Ray H., Ol

Behrooz, Majid, 09

Bertagne, Christopher L., 2F

Boccalero, Gregorio, OG

Boragno, Corrado, OG

Boyd, James G., OU

Bryant, Matthew, OD

Carrara, Matteo, 02

Cazzulani, Gabriele, 2P

Cervantes-Muñoz, Damián, 3B

Cha, Youngsu, OB

Chattaraj, Nilanjan, 1V

Chatterjee, Punnag, OD

Chen, Chao-Ting, 3D

Chen, Peng, 32

Chiu, Wing K., 2C

Choi, Seung-Bok, 08, 1L, 1N, 10, 1P, 30, 33

Choi, Seung-Hyun, 1L, IN

Chu, Kang-Yu, 3D

Chung, Jye Ung, 10, 1P, 30

Cinquemani, Simone, 1Z, 2P, 2W

Cunefare, Kenneth, 04

Daghash, S. M., 15

Darabi, A., 10

Deng, Kangfa, 12

Depraetere, B., 1C

De Rosa, R., $2 X$

Deü, Jean-François, 1A

Dhanalakshmi, K., 2T

Diana, G., $1 Z$

Dragoni, Eugenio, 2K

Elhadidi, Mohamed, OS
Enriquez-Zarate, J., $2 Z$

Erbis, Vadim, OA

Ermanni, Paolo, OY

Errico, Gianmarco, 2V

Erturk, Alper, 02, 04, 05, 0C, 10, 11

Essink, Brittany C., 23

Fava, Victor, 2V

Ferri, Brian, 11

Fossati, L., 12

Friswell, M. I., OP

Fujitani, Hideo, 27

Ganguli, Ranjan, 1V

Garcia-Pérez, O. A., 36

Ge, Cong, $1 G$

Geiyer, Daniel, 00

Gerlach, Gerald, 12

Geßner, Thomas, 13

Giberti, H., 2W

Giordano, G., 2X

Gordaninejad, Faramarz, 09

Gray, M., 05

Guenther, Margarita, 12

Guo, An-xin, 2N

Güth, Dirk, OA

Hahn, Gregory, OF

Haines, Carter, 0

Han, Young-Min, IP

Harne, R. L., OL, 1H

Hartl, Darren J., OU, 2F

Hegger, Christian, OA

Helal, Mohammed, OS

Hiraki, Yasuhiro, 37

Hobeck, Jared D., 19, 23

Holz, B., 16

Honarvar, Mohammad, 2J

Huo, Lianfeng, 2A

Hutapea, Parsaoran, 2J

Hynds, Taylor D., 2B

Ikeda, Naoto, 37

Ikeda, T., 17

Ikegame, Toru, 38

Inman, Daniel J., OT, 19, 23

Inove, Tsuyoshi, 38

Ito, Mai, 27

Jikuya, Ichiro, 38

Jung de Andrade, Monica, ol

Kaduskar, Shreya S., 20

Kagata, Hiroshi, 37

Kalkowski, Michał K., IT 
Katsumura, Hidenori, 37

Kauffman, Jeffrey L., 0O, 2B

Kim, Pyunghwa, 1L, 1N

Kim, Soomin, 1L, 1N, 1P

Kleine, R. Kaleb, OV

Konh, Bardia, 2J

Koontz, Zachary, 04

Kraus, Dustan, OV

Krishna Chaitanya, S., 2T

Kroll, Lothar, 13

Krombholz, C., 1B

Kruse, F. F., 1B

Kulpe, Jason A., 02

Kunze, J., 16

Kuo, Chun-Liang, 3D

Lagoudas, Dimitris C., OU

Lajimi, S. A. M., OP

Leadenham, Stephen M., 02, 11

Leamy, Michael J., 02, 10

Li, Hui, 2N

Li, Kaiyuan, 03

Li, Su-chao, 2N

Li, Suyi, OH

Liang, Junrui, OE, $1 \mathrm{G}$

Liao, Wei-Hsin, 1 J, 39

Lima, Marcio D., Ol

Lipowski, Mathias, 13

Liu, Haili, OE, $1 \mathrm{G}$

Liu, Kefu, OR

Liu, M., 21

Liv, Mingzhao, $1 X$

Longtin, Jon, $1 \mathrm{X}$

Lossouarn, Boris, 1A

Lozoya-Santos, Jorge de J., 3B

$\mathrm{Ma}, \mathrm{HaO}, \mathrm{lJ}$

Maas, Jürgen, $\mathrm{OA}$

Mao, Chen-xi, 2N

Mascareñas, David, OV

Masoumi, Masoud, $1 \mathrm{X}$

Masuda, Arata, 37

Meneghini, R. Michael, 1 E

Molinari, Giulio, OY

Monner, H. P., 1B

Morgan, Eric, OF

Moss, Scott D., 26, 2 C

Motzki, P., 16

Moumni, Ziad, $2 \mathrm{M}$

Mukherjee, Sujoy, IW

Nassar, Omar, OS

Oh, Jong-Soek, 1L, 1N, 33

Okumura, Hidenori, 37

Orsini, Lorenzo, 2Q

Otto, Thomas, 13

Ou, Jinping, 2A

Owen, Robert B., 23

Oyadiji, S. Olutunde, 3C

Ozbulut, O. E., 15

Palagummi, S., $O Q$

Pankonien, Alexander M., ОТ

Papalou, Angeliki, 2G
Park, Jinhyuk, 08

Payne, Owen R., 26

Perner, M., 1B

Peza-Solís, J. F., 36

Phu, Do Xuan, 10, 30

Pinte, G., $1 C$

Porfiri, Maurizio, OB

Qian, Li-Jun, 32

Ramírez Mendoza, Ricardo, 3B

Ray, Chase A., 11

Ren, J., 2 I

Resta, Ferruccio, OX, 2P, 2Q, 2V

Richardson, Guy, 20

Ripamonti, Francesco, 0X, 1Z, 2P, 2Q, 2V

Rizzo, Piervincenzo, 03

Romano, R., $2 X$

Rome, Richard S., Ol

Roubien, Denis, $2 \mathrm{G}$

Rustighi, Emiliano, $1 \mathrm{~T}$

Sas, P., $1 \mathrm{C}$

Sato, Yusuke, 27

Saunders, Robert N., OU

Sawamura, K., 17

Schipf, David R., 3D

Schirmer, Eckart, 13

Schueller, Martin, 13

Scirè Mammano, Giovanni, 2K

Seelecke, S., 16

Senba, A., 17

Shafer, Michael W., OF

Shahab, S., 05, 0C, 10

Sherif, M. M., 15

Sheth, Rubik B., $2 F$

Silva-Navarro, G., 2Z, 36

Skow, Ellen, 04

Sohn, Jung Woo, 33

Soltani, A., $2 S$

Srivastava, Swapnil, IW

Stabile, Alessandro, 20

Strepelias, Elias, 2G

Sun, A., OL

Tadesse, Yonas, 0

Takagi, Kentaro, 38

Tamayama, M., 17

Tang, J., OM

Tang, Lihua, OE, OR

Tewolde, Mahder, IX

Thota, M., 1H

Torti, Alessandro, 2P

Triantafillou, Thanasis, $2 \mathrm{G}$

Trujillo-Franco, L. G., 36

Ung, Chandarin, 26, 2C

Vandewater, Luke A., 26

Vivani, Andrea, OX

Walther, Marco, 13

Wang, D. H., 2D, 2E

Wang, Guang Qing, 39

Wang, Jian, 2A

Wang, K. W., $\mathrm{OH}, \mathrm{OL}, 1 \mathrm{H}$

Wang, Wei-Chih, 3D 
Wang, Y., 21

Wang, $Y a, 1 X$

Wankhade, Rajan L., 22

Waters, Timothy P., IT

Whitcomb, John D., 2F

Wilson, Brooke E., IE

Wu, Lianjun, 01

Wu, Wen-Jong, 3D

$\mathrm{XU}, \mathrm{J} ., \mathrm{OM}$

Yadav, Shubham Kumar, IW

Yang, Yaowen, $\mathrm{OE}$

Yang, Zhengbao, is

York, A., 16

Yoshida, Shohei, 27

Yuan, F. G., OQ

Yuan, G., 2D, 2E

Zaki, Wael, 2M

Zeyada, Yasser, OS

Zhang, Yi, 3C

Zhang, YU, OR

Zhao, G., IC

Zhao, Liya, OE

Zhao, Yagebai, 2N

Zhu, An-Ding, 32

Zou, J., OQ

Zu, Jean, 15

Proc. of SPIE Vol. $9431943101-13$

Downloaded From: https://www.spiedigitallibrary.org/conference-proceedings-of-spie on 26 Apr 2023 Terms of Use: https://www.spiedigitallibrary.org/terms-of-use 
Proc. of SPIE Vol. $9431943101-14$

Downloaded From: https://www.spiedigitallibrary.org/conference-proceedings-of-spie on 26 Apr 2023 Terms of Use: https://www.spiedigitallibrary.org/terms-of-use 


\section{Conference Committee}

Symposium Chairs

Victor Giurgiutiu, University of South Carolina (United States)

Christopher S. Lynch, University of California, Los Angeles

(United States)

Symposium Co-chairs

Jayanth N. Kudva, NextGen Aeronautics, Inc. (United States)

Theodoros E. Matikas, University of loannina (Greece)

Conference Chair

Wei-Hsin Liao, The Chinese University of Hong Kong

(Hong Kong, China)

Conference Co-chairs

Gyuhae Park, Chonnam National University (Korea, Republic of)

Alper Erturk, Georgia Institute of Technology (United States)

Conference Program Committee

Gregory S. Agnes, Jet Propulsion Laboratory (United States)

Mehdi Ahmadian, Virginia Polytechnic Institute and State University (United States)

Eric H. Anderson, Moog CSA Engineering (United States)

Hiroshi Asanuma, Chiba University (Japan)

Amr M. Baz, University of Maryland, College Park (United States)

Diann E. Brei, University of Michigan (United States)

Gregory P. Carman, University of California, Los Angeles (United States)

Seung-Bok Choi, Inha University (Korea, Republic of)

William W. Clark, University of Pittsburgh (United States)

Alison B. Flatau, University of Maryland, College Park (United States)

Farhan S. Gandhi, Rensselaer Polytechnic Institute (United States)

Ephrahim Garcia, Cornell University (United States)

Mehrdad N. Ghasemi-Nejhad, University of Hawai'i (United States)

Victor Giurgiutiu, University of South Carolina (United States)

Faramarz Gordaninejad, University of Nevada, Reno (United States)

Nakhiah C. Goulbourne, University of Michigan (United States)

Daniel J. Guyomar, Institut National des Sciences Appliquées de Lyon

(France) 
Tristram T. Hyde, NASA Headquarters (United States)

Daniel J. Inman, University of Michigan (United States)

Conor D. Johnson, Moog CSA Engineering (United States)

Hyung-Jo Jung, KAIST (Korea, Republic of)

David L. Mascareñas, Los Alamos National Laboratory (United States)

Roger Ohayon, Conservatoire National des Arts et Métiers (France)

Mohammad Rastgaar Aagaah, Massachusetts Institute of Technology (United States)

Norbert Schwesinger, Technische Universität München (Germany)

Yi-Chung Shu, National Taiwan University (Taiwan)

Henry A. Sodano, University of Florida (United States)

Steve Southward, Virginia Polytechnic Institute and State University (United States)

Roger Stanway, The University of Sheffield (United Kingdom)

Jiong Tang, University of Connecticut (United States)

Dai-Hua Wang, Chongqing University (China)

Kon-Well Wang, University of Michigan (United States)

Norman M. Wereley, University of Maryland, College Park (United States)

Hwan-Sik Yoon, The University of Alabama (United States)

Lei Zuo, Virginia Polytechnic Institute and State University

(United States)

\section{Session Chairs}

1 Energy Harvesting and Scavenging: Waves/Acoustics

Wei-Hsin Liao, The Chinese University of Hong Kong

(Hong Kong, China)

Gyuhae Park, Chonnam National University (Korea, Republic of)

2 Magneto Rheological Systems I

Norman M. Wereley, University of Maryland, College Park (United States)

3 Energy Harvesting and Scavenging: Fluid-Structure Interaction

Alper Erturk, Georgia Institute of Technology (United States)

Henry A. Sodano, University of Florida (United States)

4 Biological-inspired Systems and Bio-MEMS

Gregory P. Carman, University of California, Los Angeles

(United States)

5 Energy Harvesting and Scavenging: Broadband/Nonlinear I

Yi-Chung Shu, National Taiwan University (Taiwan) 
6 Energy Harvesting and Scavenging: Broadband/Nonlinear II

Kon-Well Wang, University of Michigan (United States)

Mustafa H. Arafa, The American University in Cairo (Egypt)

7 Aircraft, MAV/UAV, and Morphing Systems

Alison B. Flatau, University of Maryland, College Park (United States)

Nam Seo Goo, Konkuk University (Korea, Republic of)

8A Energy Harvesting and Scavenging: Piezoelectrics/Electrects

Lei Zuo, Virginia Polytechnic Institute and State University (United States)

8B Micro- and Nano-Integrated Systems

Matthew Bryant, North Carolina State University (United States)

9A SMA-Based Materials and Systems I

Darren Hartl, Texas A\&M University (United States)

Diann E. Brei, University of Michigan (United States)

9B Passive and Active Vibration Isolation Systems I

Andres F. Arrieta, ETH Zürich (Switzerland)

10A Energy Harvesting and Scavenging: General Piezoelectrics

Norbert Schwesinger, Technische Universität München (Germany)

Soobum Lee, University of Maryland, Baltimore County (United States)

1OB Modeling, Optimization, Signal Processing, Sensing, Control, and Design of Integrated Systems I

Jiong Tang, University of Connecticut (United States)

Mohammad H. Malakooti, University of Florida (United States)

11 A Magneto Rheological Systems II

Seung-Bok Choi, Inha University (Korea, Republic of)

Majid Behrooz, University of Nevada, Reno (United States)

11 B Piezo-based Materials and Systems

Alper Erturk, Georgia Institute of Technology (United States)

12A Modeling, Optimization, Signal Processing, Sensing, Control, and Design of Integrated Systems II

Francesco Ripamonti, Politecnico di Milano (Italy)

12B Passive and Active Vibration Isolation Systems II

Steven R. Anton, Tennessee Technological University (United States) 
13A Energy Harvesting and Scavenging: Applications

Ryan L. Harne, University of Michigan (United States)

Lihua Tang, The University of Auckland (New Zealand)

13B Passive and Active Vibration Isolation Systems III

Hiroshi Asanuma, Chiba University (Japan)

14A Energy Harvesting and Scavenging: General

Jeffrey L. Kauffman, University of Central Florida (United States)

14B Modeling, Optimization, Signal Processing, Sensing, Control, and Design of Integrated Systems III

Angeliki Papalou, Technological Educational Institute of Patras (Greece)

Yilan Zhang, University of Michigan (United States)

15A SMA-Based Materials and Systems II

Tadashige Ikeda, Nagoya University (Japan)

15B Passive and Active Vibration Isolation Systems IV

Dai-Hua Wang, Chongqing University (China)

Yilan Zhang, University of Michigan (United States) 